\title{
Post-Death Cloning of Endangered Jeju Black Cattle (Korean Native Cattle): Fertility and Serum Chemistry in a Cloned Bull and Cow and Their Offspring
}

\author{
Eun Young $\mathrm{KIM}^{1,2) *}$, Dong Hwan SONG ${ }^{3) *}$, Min Jee PARK ${ }^{1-3)}$, Hyo Young PARK ${ }^{1,2)}$, \\ Seung Eun $\mathrm{LEE}^{2,3)}$, Hyun Yong $\mathrm{CHO}^{2,3)}$, Jeremiah Jiman $\mathrm{MOON}{ }^{2,3)}$, Young Hoon $\mathrm{KIM}^{4)}$, \\ Seong Ho MUN ${ }^{2)}$, Chang Eon $\mathrm{OH}^{2)}$, Moon Suck $\mathrm{KO}^{5)}$, Dong Sun $\mathrm{LEE}^{3)}$, Key Zung $\mathrm{RIU}^{3)}$ and \\ Se Pill PARK ${ }^{1-3)}$ \\ 1) Mirae Biotech, Seoul 143-854, Korea \\ 2) Jeju National University Stem Cell Research Center, Seoul 143-854, Korea \\ 3) Faculty of Biotechnology, College of Applied Life Sciences, Jeju National University, Jeju 690-756, Korea \\ 4) Institute for Livestock Promotion, Jeju Special Self-Governing Province, Jeju 690-180, Korea \\ 5) National Institute of Subtropical Agriculture, Jeju 690-150, Korea
}

\begin{abstract}
To preserve Jeju black cattle (JBC; endangered native Korean cattle), a pair of cattle, namely a post-death cloned JBC bull and cow, were produced by somatic cell nuclear transfer (SCNT) in a previous study. In the present study, we examined the in vitro fertilization and reproductive potentials of these post-death cloned animals. Sperm motility, in vitro fertilization and developmental capacity were examined in a post-death cloned bull (Heuk Oll Dolee) and an extinct nuclear donor bull (BK94-13). We assessed reproductive ability in another post-death cloned cow (Heuk Woo Sunee) using cloned sperm for artificial insemination (AI). There were no differences in sperm motility or developmental potential of in vitro fertilized embryos between the post-death cloned bull and its extinct nuclear donor bull; however, the embryo development ratio was slightly higher in the cloned sperm group than in the nuclear donor sperm group. After one attempt at AI, the postdeath cloned JBC cow became pregnant, and gestation proceeded normally until day 287. From this post-death cloned sire and dam, a JBC male calf (Heuk Woo Dolee) was delivered naturally (weight, $25 \mathrm{~kg}$ ). The genetic paternity/maternity of the cloned JBC bull and cow with regard to their offspring was confirmed using International Society for Animal Genetics standard microsatellite markers. Presently, Heuk Woo Dolee is 5 months of age and growing normally. In addition, there were no significant differences in blood chemistry among the post-death cloned JBC bull, the cow, their offspring and cattle bred by AI. This is the first report showing that a pair of cattle, namely, a post-death cloned JBC bull and cow, had normal fertility. Therefore, SCNT can be used effectively to increase the population of endangered JBC.
\end{abstract}

Key words: Fertility, Jeju black cattle, Offspring, Post-death cloning, SCNT

(J. Reprod. Dev. 59: 536-543, 2013)

$\mathbf{S}^{\mathrm{o}}$ matic cell nuclear transfer (SCNT) is an effective technique that has been successfully applied to developmental biology and has resulted in the production of offspring from various species, including sheep, cattle, mice, and pigs [1-4]. It has enormous potential for basic and biomedical research as well as for the conservation of endangered species. In many cases, somatic cell cloning increases animal populations. However, the potential advantages of using SCNT in the cattle industry are not yet known because it is unclear whether somatic cell cloning negatively affects animal development and health or meat and milk products that are consumed by humans [5-8]. With recent improvements in advanced assisted reproductive

Received: May 3, 2013

Accepted: July 11, 2013

Published online in J-STAGE: August 15, 2013

(C)2013 by the Society for Reproduction and Development

Correspondence: EY Kim (e-mail: jlokey@daum.net) and SP Park (e-mail: sppark@jejunu.ac.kr)*EY Kim and DH Song contributed equally to this work. technologies, such as optimized conditions for oocyte maturation, stable enucleation using the Oosight ${ }^{\mathrm{TM}}$ imaging system [9] and in vitro freezing and thawing of embryos for direct transfer, the success rate of animal cloning is higher than previously (from $<5 \%$ to $10-20 \%)[10,11]$. Thus far, there have been no reports describing significant differences in health, pathology, and production between cattle bred conventionally or via SCNT and their offspring [12]. In addition, breeding performance after artificial insemination (AI) is similar between cloned and nuclear donor cattle [13-15].

Jeju black cattle (JBC), one of four native Korean cattle species characterized by their pitch-black coat color, live in the World Natural Heritage sites in Jeju Special Self-Governing Province. JBC are traditionally regarded as a source of top-quality food. However, they are endangered, with approximately 400 animals remaining in Jeju Special Self-Governing Province; therefore, cloning is needed to preserve these endangered animals and to further improve their traits. In a previous study, we reported the production of two JBC cloned bulls (Heuk Young Dolee, date of birth March 11, 2009; 
Heuk Oll Dolee, date of birth September 9, 2009) [10] and one JBC cloned cow (Heuk Woo Sunee, date of birth October 31, 2010) [11]. Two out of three of these animals (i.e., Heuk Oll Dolee and Heuk Woo Sunee) were post-death cloned and generated by SCNT approximately 2 years after their nuclear donors (BK94-13 and BK94-14, respectively) were slaughtered. However, no studies have examined the reproductive potential of a pair of endangered post-death cloned cattle.

The aim of this study was to examine different fertility parameters in a post-death cloned bull (Heuk Oll Dolee) and cow (Heuk Woo Sunee) by (i) comparing the motility of sperm from a cloned bull with that of its extinct nuclear donor bull (BK94-13), (ii) determining the in vitro developmental potential of embryos produced by in vitro fertilization using cloned and nuclear donor bull sperm, (iii) assessing the production of F1 offspring by the cloned cow using cloned bull sperm and AI and (iv) confirming the paternity/maternity of the cloned dam and sire.

\section{Materials and Methods}

\section{Chemicals and reagents}

Unless stated otherwise, all chemicals and reagents were purchased from Sigma Chemical Company (St. Louis, MO, USA).

\section{Oocyte collection and in vitro maturation}

Bovine ovaries were obtained from a local abattoir and transported to the laboratory within 2 to $4 \mathrm{~h}$ in phosphate buffered saline (PBS) at $37 \mathrm{C}$. Cumulus-oocyte complexes (COCs) were retrieved from antral follicles between 2 to $6 \mathrm{~mm}$ in diameter using a 19 gauge needle attached to a $10 \mathrm{ml}$ syringe. COCs with at least three cumulus cell layers were selected and washed twice with HEPES-buffered Tyrode's medium. Groups of ten COCs were cultured in $50 \mu 1$ droplets of TCM-199 maturation medium (Gibco, Grand Island, NY, USA) supplemented with $10 \%$ fetal bovine serum (FBS, Gibco), $0.2 \mathrm{mM}$ sodium pyruvate, $1 \mu \mathrm{g} / \mathrm{ml}$ FSH (Folltropin-V; Bioniche Animal Health, Belleville, ON, Canada), $1 \mu \mathrm{g} / \mathrm{ml}$ estradiol $-17 \beta$ and $25 \mu \mathrm{g} / \mathrm{ml}$ gentamicin. Droplets were covered with mineral oil and incubated at $38.8 \mathrm{C}$ in an atmosphere of $5 \% \mathrm{CO}_{2}, 5 \% \mathrm{O}_{2}$ and $90 \% \mathrm{~N}_{2}$.

\section{Production of the sire and dam by somatic cell nuclear transfer}

Somatic cell cloned male and female calves (Heuk Oll Dolee and Heuk Woo Sunee, respectively) derived from JBC (Bos taurus coreanae; native Korean cattle) were produced as described previously $[10,11]$. In brief, the cloned sire and dam were produced from nuclear donor cells obtained from an extinct elite bull (BK94-13) and cow (BK94-14), respectively. Ear tissues were donated by the Institute for Livestock Promotion, Jeju Special Self-Governing Province 1 year before slaughter (in 2008) due to old age (14 years) and were used to clone the elite JBC. The tissues were mechanically dissected and incubated in $0.1 \%$ collagenase type IV at $38 \mathrm{C}$ for $1.5 \mathrm{~h}$. Cells were cultured in donor cell culture medium [Dulbecco's modified Eagle's medium containing 10\% FBS, $1 \mathrm{mM}$ sodium pyruvate, $1 \%$ nonessential amino acids, $0.1 \% \beta$-mercaptoethanol and $1 \%$ penicillin-streptomycin]. The cells were grown and subcultured $3-5$ times at intervals of 4-6 d, and then $1 \times 10^{6}$ cells were frozen in freezing medium (50\% donor cell culture medium containing $45 \%$
FBS and 5\% DMSO) in a $1.5 \mathrm{ml}$ cryovial.

For SCNT, thawed ear cells were plated in a culture dish with donor cell culture medium and cultured for $2-3 \mathrm{~d}$ before preparation as donor cells. On the day of the experiment, donor cells were recovered using TrypLE solution, washed three times and treated with $3 \mathrm{mg} /$ $\mathrm{ml}$ protease for $50 \mathrm{~s}$ at room temperature. Donor cells were then washed three times and resuspended in donor cell preparation medium [TCM199-HEPES (Gibco) supplemented with $0.2 \mathrm{mM}$ sodium pyruvate]. For enucleation, the metaphase II plate and first polar body were visualized under an inverted microscope (Olympus, Tokyo, Japan) equipped with an Oosight ${ }^{\mathrm{TM}}$ spindle-check system (CRi, Hopkinton, MA, USA) and removed by the squeezing method. A single treated donor cell was placed in the perivitelline space of the enucleated oocyte in nuclear transfer medium [TCM199-HEPES containing $0.6 \%$ fatty acid-free (FAF) BSA and $10 \mu \mathrm{g} / \mathrm{ml}$ phytohaemagglutinin] through the opening made during enucleation. Oocyte-donor cell couplets were placed in cell fusion medium ( $0.3 \mathrm{M}$ mannitol, 0.5 mM HEPES, $0.05 \mathrm{mM} \mathrm{CaCl}_{2}$ and $0.1 \mathrm{mM} \mathrm{MgSO}_{4}$ ) and subjected to an electrical pulse of $1.3 \mathrm{kV} / \mathrm{cm}$ for $20 \mu \mathrm{sec}$ (delivered via an Electro Cell Fusion Generator, Model LF101; NEPA\#GENE, Chiba, Japan). After fusion, the reconstructed embryos were maintained in TCM199-HEPES supplemented with 20\% FBS for $1 \mathrm{~h}$, activated in $10 \mu \mathrm{M}$ calcium ionophore for $5 \mathrm{~min}$ and then exposed to $2 \mathrm{mM}$ 6-dimethylaminopurine for $3 \mathrm{~h}$. After activation, the reconstructed embryos were cultured in CR 1 aa medium supplemented with $0.3 \%$ FAF-BSA for $2 \mathrm{~d}$. They were then cocultured for $6 \mathrm{~d}$ on the same JBC ear feeder cells in CR1 aa medium containing 10\% FBS, $1 \mu \mathrm{M}$ EGF and $1 \mu \mathrm{M} \mathrm{IGF}$ at $38.8 \mathrm{C}$ in an atmosphere of $5 \% \mathrm{CO}_{2}, 5 \% \mathrm{O}_{2}$ and $90 \% \mathrm{~N}_{2}$ [9].

Fresh embryos that developed into blastocysts (in the case of Heuk Oll Dolee) or blastocysts thawed by a direct transfer freezing method (in the case of Heuk Woo Sunee) [11] were transferred into Hanwoo (another name for Korean native cattle) recipient cows. Live-born offspring (somatic cell clones) were housed and fed under standard conditions. These procedures produced Heuk Oll Dolee, a male (date of birth September 9, 2009), and Heuk Woo Sunee, a female (date of birth October 31, 2010), approximately 2 years after slaughter of their nuclear donor.

\section{Production of a calf from the cloned sire and dam}

Semen was collected from the cloned 25-month-old JBC bull (Heuk Oll Dolee) using an artificial vagina. Semen samples with $>$ $80 \%$ motile spermatozoa were frozen by ultrarapid freezing using $20 \%$ egg yolk extender. Semen was loaded into $0.5 \mathrm{ml}$ plastic straws (50 million spermatozoa/straw) and subsequently stored in liquid nitrogen until used for in vitro fertilization (IVF) or AI. The cloned cow (Heuk Woo Sunee) was artificially inseminated during estrus using thawed semen from the cloned bull. Pregnancy was confirmed by ultrasonography at $50 \mathrm{~d}$ post $\mathrm{AI}$, and the uterine cotyledon size was estimated by rectal ultrasonography at $150 \mathrm{~d}$ post AI.

\section{Sperm analysis}

The motility of sperm in the thawed semen from Heuk Oll Dolee and that from a nuclear donor bull (BK94-13) was assessed using a sperm analysis imaging system (SAIS Plus; Medical Supply, Wonju, Gangwon, Korea). Frozen semen from an extinct BK94-13 bull was 
obtained from the Livestock Development Agency for comparison. Briefly, the thawed semen was placed in a $10 \mu \mathrm{m}$ standard counting chamber. Five random fields of view were selected for each analysis. Sperm motility was assessed according to the following parameters: straight line velocity (VSL), which is the average velocity measured in a straight line from the beginning to the end of a track $(\mu \mathrm{m} / \mathrm{s})$; the amplitude of the lateral head displacement (ALH), which is the width of the head oscillation as the sperm swims $(\mu \mathrm{m})$; and curvilinear velocity (VCL), which is the point to point velocity (total distance traveled) per second multiplied by two to give the full width and total motility.

\section{In vitro fertilization and in vitro culture}

At $22 \mathrm{~h}$ post IVM, COCs were transferred into TL-STOCK medium (114 mM NaCl, $3.2 \mathrm{mM} \mathrm{KCl}, 25 \mathrm{mM} \mathrm{NaHCO}{ }_{3}, 0.4 \mathrm{mM}$ $\mathrm{NaH}_{2} \mathrm{PO}_{4} \cdot \mathrm{H}_{2} \mathrm{O}, 2 \mathrm{mM} \mathrm{CaCl} 2.2 \mathrm{H}_{2} \mathrm{O}, 0.5 \mathrm{mM} \mathrm{MgCl} 2.6 \mathrm{H}_{2} \mathrm{O}, 10$ $\mathrm{mM}$ Na-lactate and $0.2 \mathrm{mM} \mathrm{Na}$-pyruvate) containing $6 \mathrm{mg} / \mathrm{ml}$ FAF-BSA and inseminated with $2 \mu$ of highly motile sperm $(2.5$ $\times 10^{7}$ spermatozoa $/ \mathrm{ml}$ ) recovered from thawed semen from Heuk Oll Dolee or from the extinct nuclear donor bull. Two microliters each of heparin $(2 \mu \mathrm{g} / \mathrm{ml})$ and PHE (18.2 M penicillamine, 9.1 $\mathrm{M}$ hypotaurine and $1.8 \mathrm{M}$ epinephrine) were also added into the 44- $\mu$ I IVF drop. Sperm was prepared using the two-step swim-up protocol (patent no: KR101064415) [16]. To remove the egg yolk, thawed semen was slowly added to $3 \mathrm{ml}$ of $20 \%$ Triladyl ${ }^{\circledR}$ solution $\left(\right.$ Trilady $l^{\circledR}:$ distilled water $\left.=1: 4\right)$ and centrifuged at $200 \mathrm{~g}(2000 \mathrm{rpm})$ for $1 \mathrm{~min}$. After aspirating the supernatant, $1 \mathrm{ml}$ of $20 \%$ Triladyl $^{\circledR}$ solution was gently layered on top of the sperm pellet and incubated at $38 \mathrm{C}$ for $15 \mathrm{~min}$ for the first swim-up. The upper part of the solution containing motile sperm was transferred into a new $15 \mathrm{ml}$ conical tube, and $1 \mathrm{ml}$ of SP-TALP $(100 \mathrm{mM} \mathrm{NaCl}, 3.1 \mathrm{mM} \mathrm{KCl}$, $25 \mathrm{mM} \mathrm{NaHCO}, 10 \mathrm{mM}$ HEPES, $0.29 \mathrm{mM} \mathrm{NaH}{ }_{2} \mathrm{PO}_{4} \cdot \mathrm{H}_{2} \mathrm{O}, 2.1$ $\mathrm{mM} \mathrm{CaCl} 2.2 \mathrm{H}_{2} \mathrm{O}, 0.4 \mathrm{mM} \mathrm{MgCl} 2.6 \mathrm{H}_{2} \mathrm{O}, 21.6 \mathrm{mM}$ Na-lactate and $1 \mathrm{mM}$ Na-pyruvate) containing $6 \mathrm{mg} / \mathrm{ml} \mathrm{FAF-BSA}$ was added. The solution was then pelleted by centrifugation at $200 \mathrm{~g}$ for $1 \mathrm{~min}$. After the supernatant was discarded, the second swim-up procedure was performed using $1 \mathrm{ml}$ of SP-TALP for $15 \mathrm{~min}$. Finally, the recovered motile sperm were counted in a hemocytometer and concentrated to $2.5 \times 10^{7}$ cells $/ \mathrm{ml}$. After $44 \pm 2 \mathrm{~h}$ of incubation, cleaved embryos were incubated in CR1aa medium containing $3 \mathrm{mg} / \mathrm{ml}$ of FAF-BSA and cultured for $2 \mathrm{~d}$. The embryos were then cultured in CR1aa medium containing $10 \% \mathrm{FBS}$ for $4 \mathrm{~d}$ at $38.8 \mathrm{C}$ in an atmosphere of $5 \% \mathrm{CO}_{2}, 5 \% \mathrm{O}_{2}$ and $90 \% \mathrm{~N}_{2}$.

\section{DNA analysis}

DNA from the cloned sire and dam, and their offspring produced by AI, were analyzed using 11 International Society of Animal Genetics (ISAG) standard microsatellite markers (TGLA227, BM2113, TGLA53, ETH10, SPS115, TGLA126, TGLA122, INRA23, ETH3, ETH225 and BM1824) [10, 11]. In brief, a QIAamp DNA Micro Kit (QIAGEN) was used to isolate genomic DNA from umbilical cord tissue obtained during delivery. Bovine autosomal microsatellite markers were then amplified by polymerase chain reaction (PCR) with fluorescent-labeled primers. PCR product polymorphisms were analyzed by electrophoresis using an Applied Biosystems 3130XL Genetic Analyzer (Applied Biosystems, Life Technologies, Carlsbad,
CA, USA) and GeneMapper ID software (version 3.2, Applied Biosystems, Life Technologies).

\section{Health status of the clones and their offspring}

A clinical examination and serum chemistry tests were performed on the sire, the dam, and their offspring. Body weights and rectal temperatures were measured. Serum blood analysis determined hematocrit, white and red blood cell counts and platelet counts using the MASCOT ${ }^{\circledR}$ hematology profile and a HEMAVET ${ }^{\mathrm{TM}}$ hematology analyzer (Model 950 FS; Drew Scientific, Waterbury, CT, USA). Serum chemistry analysis assayed the concentrations of Ca electrolytes, glucose, blood urinary nitrogen (BUN), creatinine, total cholesterol (TCHO), total bilirubin (TBIL), total protein (TP), albumin, glutamic oxaloacetic transaminase (GOT) and glutamic pyruvic transaminase (GPT). Serum blood analyses included control serum obtained from four JBC bred normally by AI. Blood was collected from the jugular vein from all animals.

\section{Experimental design}

To examine the fertility and reproductive potential of one pair of animals, namely, a post-death cloned bull (Heuk Oll Dolee) and cow (Heuk Woo Sunee), the motility of sperm in thawed semen from the cloned bull and its extinct nuclear donor bull (BK94-13) was assessed using the sperm analysis imaging system, and the in vitro developmental potential of embryos produced by IVF using cloned and nuclear donor bull sperm was compared. All experiments were repeated three times. To assess the production ability of F1 offspring, the cloned cow was artificially inseminated with thawed semen from the cloned bull. The maternity/paternity of the cloned dam and sire was also confirmed. In addition, a clinical examination of the post-death cloned family and a blood chemistry analysis were performed.

\section{Statistical analysis}

Data from IVF experiments were compiled from at least three independent experiments. Binominal data from cell cleavage and blastocyst development experiments were converted to percentages. Scores representing embryo developmental rates were evaluated by one-way analysis of variance (ANOVA) with randomized block analysis (linear mixed model) using SPSS (version 16). P values $\leq 0.05$ were considered significant.

\section{Results}

Sperm motility analysis in the cloned and nuclear donor bulls

Sperm quality in the cloned and nuclear donor bulls was assessed using the SAIS Plus program (Table 1). A comparison of the motility of thawed sperm from the nuclear donor, BK94-13, and its clone, Heuk Oll Dolee, showed that motility $(93.3 \%)$, VCL $(188.6 \mu \mathrm{m} / \mathrm{s})$, $\operatorname{VSL}(48.2 \mu \mathrm{m} / \mathrm{s})$ and VAP $(97.1 \mu \mathrm{m} / \mathrm{s})$ were higher in the cloned sperm than in the nuclear donor sperm $(90.7 \%, 183.3 \mu \mathrm{m} / \mathrm{s}, 41.4$ $\mu \mathrm{m} / \mathrm{s}$ and $88.7 \mu \mathrm{m} / \mathrm{s}$ for motility, VCL, VSL and VAP, respectively). However, there was no difference in ALH between cloned and nuclear donor sperm. 
Table 1. SAIS analysis of thawed semen from the extinct JBC elite bull (BK94-13) and post-death cloned bull (Heuk Oll Dolee)*

\begin{tabular}{lcccc}
\hline \multirow{2}{*}{ Parameter** } & Unit & \multicolumn{2}{c}{ Result } & \multirow{2}{*}{ Reference } \\
\cline { 3 - 4 } & & BK94-13 & Heuk Oll Dolee & \\
\hline No. of fields analyzed & Fields & 5 & 5 & \\
No. of sperm analyzed & Cells & 410.2 & 450.8 & $>>100$ \\
Concentration & Millions & 27.2 & 29.8 & \\
Total concentration & Millions/ml & 135.8 & 149.2 & $>>20$ \\
Motility & $(\%)$ & 90.7 & 93.3 & $>>50$ \\
VCL (curvilinear velocity) & $\mu \mathrm{m} / \mathrm{sec}$ & 183.3 & 188.6 & $>>46$ \\
VSL (straight-line velocity) & $\mu \mathrm{m} / \mathrm{sec}$ & 41.4 & 48.2 & $>>26$ \\
VAP (average path velocity) & $\mu \mathrm{m} / \mathrm{sec}$ & 88.7 & 97.1 & \\
Lin (linearity) & & 24.1 & 26.7 & $>>58$ \\
ALH (amplitude of lateral head displacement) & $\mu \mathrm{m}$ & 4.3 & 4.3 & $>>2.4$ \\
STR (straightness) & & 46.4 & 49.2 & \\
BCF (beat-cross frequency) & Hz & 9.3 & 9.7 & \\
MAD (mean angular displacement) & Degrees & 54.6 & 57.3 & \\
WOB (wobble) & & 48.3 & 51.4 & \\
\hline
\end{tabular}

* The experiment was replicated three times. ** Semen collection time: BK 94-13 (at 13 years of age) and Heuk Oll Dolee (at 25 months of age).

Table 2. Developmental potential of bovine IVF embryos using thawed sperm from the extinct JBC elite bull (BK94-13) and postdeath cloned bull (Heuk Oll Dolee) $(r=3)$

\begin{tabular}{lcccc}
\hline \multirow{2}{*}{ Bull No.* } & No. of & \multicolumn{3}{c}{ No. (\%) of embryos developed to } \\
\cline { 3 - 5 } & oocytes & $\begin{array}{c}\text { Day } 2 \geq 2 \\
\text { cell }\end{array}$ & $\begin{array}{c}\text { Day 6 } 2 \\
\text { morulae }\end{array}$ & $\begin{array}{c}\text { Day } 8 \geq \\
\text { blastocyst }\end{array}$ \\
\hline BK94-13 & 155 & $113(72.9)$ & $64(56.6)$ & $32(28.3)$ \\
Heuk Oll Dolee & 163 & $125(76.7)$ & $74(59.2)$ & $38(30.4)$ \\
\hline
\end{tabular}

* BK94-13 is an extinct JBC bull that was slaughtered in 2008; its semen was cryopreserved in 2007 (13 years of age). Heuk Oll Dolee is a cloned bull that was produced in 2009 from the somatic cells of BK94-13; its semen was cryopreserved in 2011 ( 25 months of age).

\section{Developmental potential of IVF embryos generated using cloned and nuclear donor bull sperm}

There was no difference in the developmental potential of bovine IVF embryos produced from cloned (76.7\%, 59.2\%, and 30.4\%) or nuclear donor $(72.9 \%, 56.6 \%$, and $28.3 \%)$ sperm at 2,6 , and $8 \mathrm{~d}$, respectively (Table 2). Embryo morphology was also similar between the two (Heuk Oll Dolee versus BK94-13); however, the rate of hatching development was slightly faster in embryos derived from Heuk Oll Dolee than in those derived from BK94-13 (Fig. 1).

\section{Production of a calf from a cloned sire and dam}

The post-death cloned sire, Heuk Oll Dolee, was delivered by caesarean section on September 9, 2009, after a gestation period of $292 \mathrm{~d}$ and had a birth weight of $27 \mathrm{~kg}$. The post-death cloned dam, Heuk Woo Sunee, was born by vaginal delivery on October 31, 2010 , after a gestation period of $299 \mathrm{~d}$ and had a birth weight of 36 $\mathrm{kg}$. To assess the fertility of these cattle at 17 months of age, thawed sperm from Heuk Oll Dolee was introduced into the uterine body of
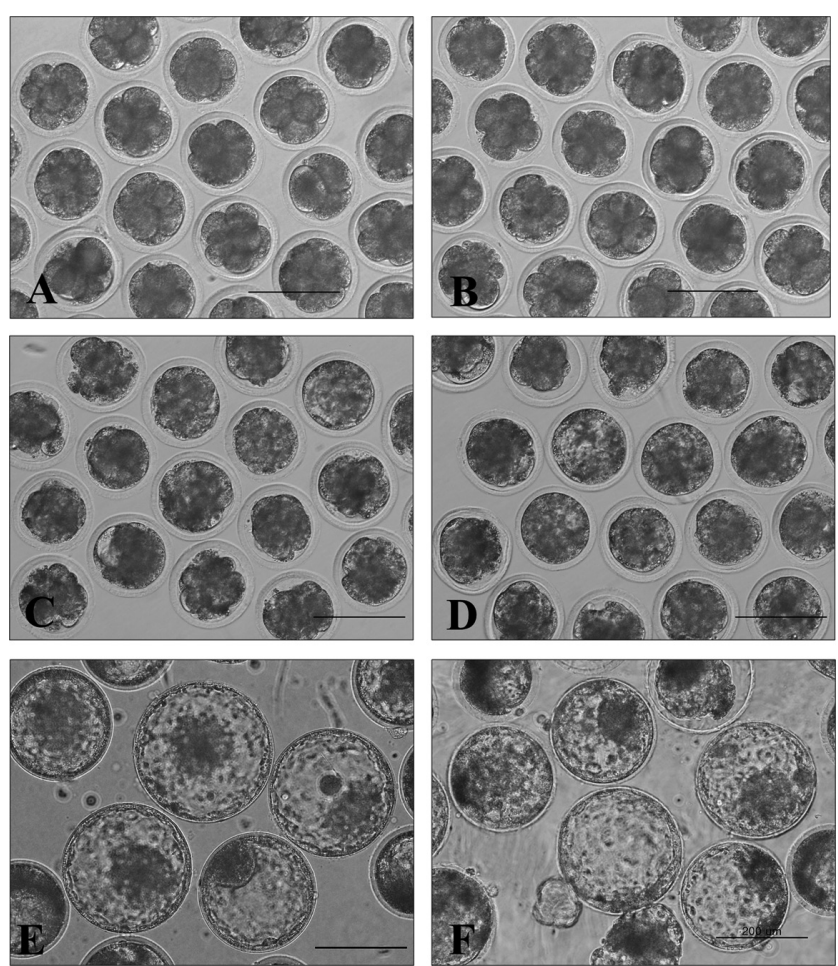

Fig. 1. Morphology of bovine IVF embryos produced from thawed sperm obtained from an extinct JBC bull (BK94-13; A, C and E) and a post-death cloned bull (Heuk Oll Dolee; B, D and F). There were no differences in morphology between the two at 2 (A and B), 6 (C and D) and 8 (E and F) d, respectively. Bars, $200 \mu \mathrm{m}$. 


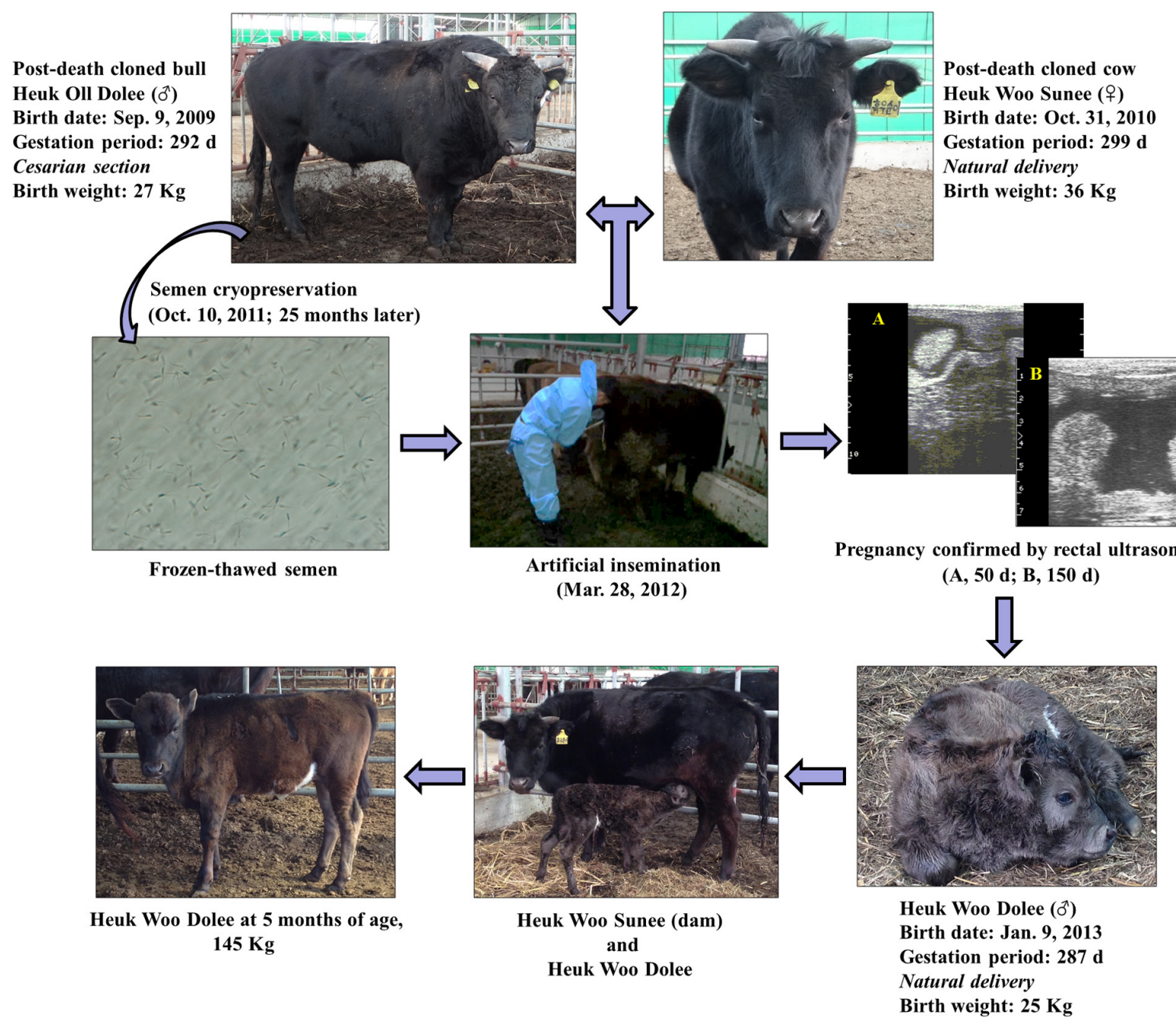

Fig. 2. Flowchart illustrating the procedure used to assess the reproductive potential of the post-death cloned bull (Heuk Oll Dolee) and cow (Heuk Woo Sunee). A male calf (Heuk Woo Dolee) was produced by the cloned sire and dam after artificial insemination with frozenthawed semen. The calf was born by vaginal delivery.

Heuk Woo Sunee approximately $12 \mathrm{~h}$ after the initiation of estrus. Pregnancy was confirmed by rectal ultrasonography at 50 and 150 $\mathrm{d}$ post $\mathrm{AI}$, and the size of the uterine cotyledon was estimated $(\leq 25$ $\mathrm{mm})$. A male calf, Heuk Woo Dolee, weighing $25 \mathrm{~kg}$ was born by vaginal delivery on January 9, 2013, after a gestation period of 287 d. At present (June 2013), 5 months after birth, the body weight of Heuk Woo Dolee is $140-150 \mathrm{~kg}$, with a daily weight gain of approximately $750-800 \mathrm{~g}$ (Fig. 2). His growth rate is $20 \%$ faster than that of other JBC cattle of the same age.

Confirming the genetic paternity/maternity of the cloned bull and cow with regard to their offspring

Eleven ISAG standard microsatellite polymorphism markers (TGLA227, BM2113, TGLA53, ETH10, SPS115, TGLA126, TGLA122, INRA23, ETH3, ETH225 and BM1824) were used to confirm the biological relationship between the cloned bull (Heuk Oll Dolee), the cloned cow (Heuk Woo Sunee), and their F1 offspring
(Heuk Woo Dolee) (Fig. 3A, B). This analysis revealed that Heuk Oll Dolee and Heuk Woo Sunee are the biological sire and dam of Heuk Woo Dolee, because they shared all alleles at 11 out of 11 loci.

\section{Health status of the clones and their offspring}

Except for moderate changes in the concentrations of glucose and GOT in the calf during development, there were no significant differences in blood chemistry among the cloned cattle, their offspring and four normal breeding groups (Table 3). All animals were healthy and developed normally.

\section{Discussion}

This is the first report to describe the fertility and reproductive potential of a pair of post-death cloned cattle, namely, a JBC bull (Heuk Oll Dolee) and a cow (Heuk Woo Sunee). When the sperm motility and developmental potential of a post-death cloned bull 

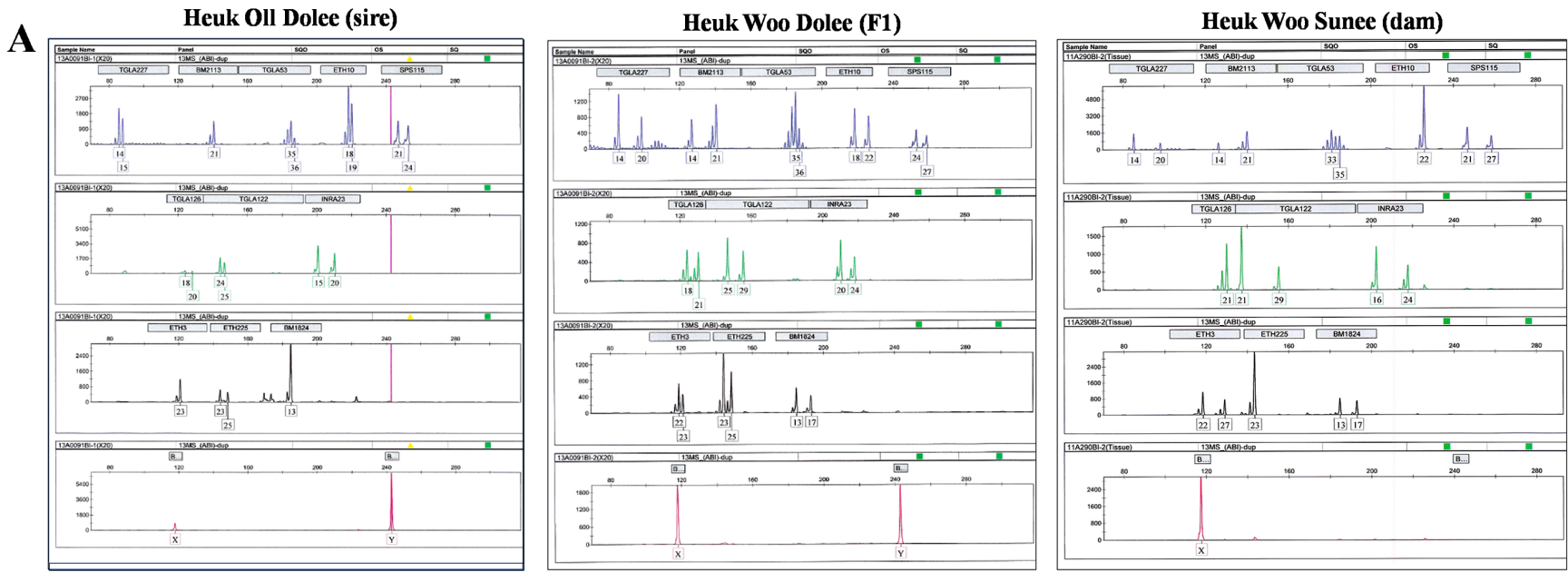

$\mathrm{B}$

\begin{tabular}{|c|c|c|c|c|c|c|}
\hline \multirow{3}{*}{$\begin{array}{l}\text { Name } \\
\text { Gender } \\
\text { Locus }\end{array}$} & \multicolumn{2}{|c|}{$\begin{array}{l}\text { Heuk Oll Dolee } \\
\text { (sire) }\end{array}$} & \multicolumn{2}{|c|}{$\begin{array}{l}\text { Heuk Woo Dolee } \\
\text { (F1) }\end{array}$} & \multicolumn{2}{|c|}{$\begin{array}{l}\text { Heuk Woo Sunee } \\
\text { (dam) }\end{array}$} \\
\hline & \multicolumn{2}{|c|}{$X Y$} & \multicolumn{2}{|c|}{$X Y$} & \multicolumn{2}{|c|}{$x x$} \\
\hline & Allele 1 & Allele 2 & Allele 1 & Allele 2 & Allele 1 & Allele 2 \\
\hline TGLA227 & 14 & 15 & 14 & 20 & 14 & 20 \\
\hline BM2113 & 21 & 21 & 14 & 21 & 14 & 21 \\
\hline TGLA53 & 35 & 36 & 35 & 36 & 33 & 35 \\
\hline ETH10 & 18 & 19 & 18 & 22 & 22 & 22 \\
\hline SPS115 & 21 & 24 & 24 & 27 & 21 & 27 \\
\hline TGLA126 & 18 & 20 & 18 & 21 & 21 & 21 \\
\hline TGLA122 & 24 & 25 & 25 & 29 & 21 & 29 \\
\hline INRA23 & 15 & 20 & 20 & 24 & 16 & 24 \\
\hline ETH3 & 23 & 23 & 22 & 23 & 22 & 27 \\
\hline ETH225 & 23 & 25 & 23 & 25 & 23 & 23 \\
\hline BM1824 & 13 & 13 & 13 & 17 & 13 & 17 \\
\hline
\end{tabular}

*The shared alleles between Heuk Oll Dolee and F1 (Heuk Woo Dolee) are represented in blue.

*The shared alleles between Heuk Woo Sunee and F1 (Heuk Woo Dolee) are represented in green.

Fig. 3. Confirmation of the biological relationship between the cloned sire (Heuk Oll Dolee) and cloned dam (Heuk Woo Sunee) and their F1 offspring (Heuk Woo Dolee). STR analysis (A) revealed that Heuk Oll Dolee and Heuk Woo Sunee were the biological sire and dam of Heuk Woo Dolee, as they shared all alleles at 11 out of 11 loci (B).

and extinct donor bull (BK94-13) were examined after IVF, there were no differences between the animals. However, sperm quality (concentration, motility, VCL, VSL, VAP, LIN and STR) was better and the hatching growth rate was higher in the young cloned bull (semen collection at 25 months of age) than in the old extinct nuclear donor (semen collection at 13 years of age). By conventional $\mathrm{AI}$, a male calf was born from the post-death cloned cow, and its genetic paternity was verified using 11 ISAG standard microsatellite polymorphism markers. A clinical examination and blood biochemistry tests revealed no differences between the cloned sire and dam and their offspring when compared with normally bred JBC. These results demonstrate that elite cattle can be preserved effectively by somatic cell cloning, and they are in agreement with those of previously published reports $[5,13]$.

In Korea, there are four native cattle breeds that are distinguished by three coat color patterns: a brown or red cattle breed (Hanwoo), a black-striped brown cattle breed (Korean brindle cattle, also called
Chick-so) and two black cattle breeds. The two indigenous black cattle breeds can be separated according to locality: the mainland (Korean black cattle) or Jeju Island (JBC). The popular cattle breed Hanwoo has the largest population, which is estimated to be approximately 2.8 million heads, whereas the other three breeds are less numerous [17]. JBC, characterized by their pitch-black coat color, are traditionally regarded as a source of top-quality food that has several health benefits. JBC beef was regularly consumed by the Korean royal family since the Goryeo Kingdom era because it is a chewy meat fillet with excellent elasticity and fine marbling, and it contains tightly lodged unsaturated fatty acids such as oleic and linoleic acids [18]. JBC are an endangered breed, which prompted initiation of the JBC Conservation Program in the early 1990s. After its gained protection as an endangered species, the JBC population increased to its present number of 400 head. Recently, the Korean Cultural Heritage Administration designated JBC as a Natural Monument of State-designated Cultural Heritage, recognizing their 
Table 3. Clinical examination and blood chemistry results for the pair of post-death cloned cattle, their offspring and normallybred JBC bulls and cows

\begin{tabular}{|c|c|c|c|c|c|c|c|c|c|}
\hline \multirow{2}{*}{ Parameter* } & \multirow{2}{*}{ Units } & \multirow{2}{*}{ Reference } & \multicolumn{2}{|c|}{ Cloned cattle } & \multirow{2}{*}{$\begin{array}{l}\text { Calf of } \\
\text { the clones }\end{array}$} & \multicolumn{2}{|c|}{ JBC bull } & \multicolumn{2}{|c|}{ JBC cow } \\
\hline & & & Dam & Sire & & I & II & I & II \\
\hline Age at exam & Months & - & 30 & 43 & 4 & 5 & 40 & 37 & 51 \\
\hline Body weight & $\mathrm{kg}$ & - & 370 & 750 & 68 & 72 & 680 & 420 & 450 \\
\hline Rectal temp. & $\mathrm{C}$ & $38.0-39.0$ & 38.0 & 38.5 & 38.6 & 39.0 & 38.0 & 38.4 & 38.3 \\
\hline WBC & $\mathrm{K} / \mu \mathrm{l}$ & $4.0-12.0$ & 8.74 & 8.80 & 9.90 & 6.80 & 9.16 & 12.7 & 12.32 \\
\hline $\mathrm{RBC}$ & $\mathrm{M} / \mu 1$ & $5.0-10.0$ & 8.90 & 6.82 & 11.45 & 12.29 & 7.59 & 7.42 & 7.84 \\
\hline Hemoglobin & $\mathrm{g} / \mathrm{dl}$ & $8.0-15.0$ & 10.3 & 9.0 & 11.5 & 9.6 & 11.1 & 9.2 & 10.2 \\
\hline Hematocrit & $\%$ & $24.0-46.0$ & 32.5 & 28.1 & 34.8 & 35.3 & 34.3 & 28.1 & 31.4 \\
\hline Platelets & $\mathrm{K} / \mu 1$ & 200-800 & 243 & 286 & 273 & 231 & 190 & ND & 290 \\
\hline $\mathrm{Ca}$ & $\mathrm{mg} / \mathrm{dl}$ & $8.4-11.0$ & 11.0 & 10.3 & 12.5 & 12.0 & 9.3 & 9.2 & 9.8 \\
\hline Glucose & $\mathrm{mg} / \mathrm{dl}$ & $45.0-75.0$ & 74 & 77 & 103 & 75 & 82 & 70 & 66 \\
\hline BUN & $\mathrm{mg} / \mathrm{dl}$ & $7.8-25.0$ & 7.6 & 11.7 & 4.4 & 9.9 & 14.6 & 12.9 & 11.6 \\
\hline Creatinine & $\mathrm{mg} / \mathrm{dl}$ & $0.6-1.8$ & 1.1 & 2.0 & 0.1 & 0.9 & 1.7 & 1.2 & 1.1 \\
\hline TCHO & $\mathrm{mg} / \mathrm{dl}$ & $62-193$ & 245 & 226 & 187 & 125 & 105 & 99 & 97 \\
\hline Total bilirubin & $\mathrm{mg} / \mathrm{dl}$ & $0-0.8$ & 0.7 & 0.6 & 0.7 & 0.4 & 0.2 & 0.3 & 0.4 \\
\hline Total protein & $\mathrm{g} / \mathrm{dl}$ & $6.2-8.2$ & 7.7 & 8.4 & 6.5 & 6.8 & 7.3 & 7.7 & 7.7 \\
\hline Albumin & $\mathrm{g} / \mathrm{dl}$ & $2.8-3.9$ & 4.2 & 3.8 & 4.0 & 3.6 & 3.7 & 3.1 & 3.4 \\
\hline GOT & $\mathrm{U} / \mathrm{I}$ & $45-110$ & 59 & 86 & 127 & 73 & 68 & 59 & 83 \\
\hline GPT & $\mathrm{U} / \mathrm{I}$ & $7-35$ & 20 & 8 & 15 & 26 & 16 & 24 & 18 \\
\hline
\end{tabular}

* WBC, white blood cells; RBC, red blood cells; BUN, blood urinary nitrogen; TCHO, total cholesterol; GOT, glutamic oxalacetic transaminase; and GPT, glutamic pyruvic transaminase. ND: Not determined.

cultural and historical value.

SCNT is used in both basic and biomedical research $[19,20]$, as well as for the conservation of endangered species [21]. We previously produced a cloned bull (Heuk Oll Dolee) and cow (Heuk Woo Sunee) from two extinct JBC elite nuclear donors, BK94-13 and BK94-14, respectively $[10,11]$, which are the sire and dam of the calf produced in the present study. In our previous study, we optimized SCNT using the Oosight ${ }^{\mathrm{TM}}$ imaging system, which provides safe and effective enucleation [9], and by performing embryo transfer of frozen-thawed SCNT blastocysts using the vitrification/one-step dilution/direct transfer system [11]. While somatic cell cloning can be injurious to oocytes, cloning is possible with the appropriate technical skill and optimal culture conditions.

Cloned embryos may also contain epigenetic errors that result in embryo or fetus loss during differentiation and development [22]. The survival of cloned cattle embryos and fetuses can be likened to the process of natural selection, because cloned cattle that reach adulthood show normal reproductive potential [14, 23]. This study aimed to determine whether a pair of post-death cloned cattle had similar reproductive potential to that of normally-bred cattle. Both the cloned bull (Heuk Oll Dolee) and the extinct donor bull (BK94-13) possessed good quality sperm of normal concentration and motility. Sperm from the cloned bull was successfully used for IVF, with no difference in the developmental potential of IVF embryos produced from sperm donated by the post-death cloned bull or the extinct nuclear donor bull; however, the developmental rate of the embryos produced from frozen-thawed sperm of the younger bull, Heuk Oll Dolee, was slightly higher.

AI has also been carried out in cloned animals to confirm the fertility of cattle $[13,24]$. This study showed that sperm from the cloned bull (Heuk Oll Dolee) could be used for AI. After one attempt, Heuk Woo Sunee became pregnant by AI using sperm from the cloned bull, with no complications during conception. The gestation period was $287 \mathrm{~d}$, and a male calf (Heuk Woo Dolee; 25 $\mathrm{kg}$ ) was born by a vaginal delivery, with no assistance from animal attendants and staff. In addition, the offspring stood on all four hooves within 20 min of birth and suckled the dam's breast. These results demonstrated that the post-death cloned JBC bull and cow had normal reproductive potential.

Genetic paternity/maternity was confirmed using 11 ISAG standard STR markers. The F1 offspring, the cloned dam, and the cloned sire shared all alleles at 11 out of 11 loci. At present ( 5 months later; June 2013) the body weight of Heuk Woo Dolee is $140-150 \mathrm{~kg}$ and increasing gradually, with a daily weight gain of approximately $750-800 \mathrm{~g}$. His growth rate is $20 \%$ faster than that of other JBC cattle of the same age. Although some parameters of blood chemistry were variable, depending on the season, feeding conditions and age, there were no significant differences between the cloned cattle, their offspring and four normally bred cattle. All animals were healthy and developed normally. While elite bull sperm may help to increase the population of $\mathrm{JBC}$, the use of cloned animals for human consumption requires greater social and regulatory acceptance [13]. In conclusion, this study showed that a pair of cattle, namely a post-death cloned JBC bull and cow, showed normal fertility and that SCNT can be used to increase the number of endangered JBC. 


\section{Acknowledgments}

We are grateful to Jeju Special Self-Governing Province Veterinary Service Laboratory for technical support. This study was supported by grants from the Fisheries Cooperative Research Program for Agriculture Science \& Technology Development (PJ009103) of the Rural Development Administration; the NextGeneration BioGreen 21 Program (PJ009075) of the Ministry for Food, Agriculture, Forestry; and the Bio-industry Technology Development Program (308008-5), Republic of Korea.

\section{References}

1. Campbell KHS, McWhir J, Ritchie WA, Wilmut I. Sheep cloned by nuclear transfer from a cultured cell line. Nature 1996; 380: 64-66. [Medline]

2. Cibelli JB, Stice SL, Golueke PJ, Kane JJ, Jerry J, Blackwell C, Ponce de Leon FA, Robl JM. Cloned transgenic calves produced from nonquiescent fetal fibroblasts. Science 1998; 280: 1256-1258. [Medline]

3. Wakayama T, Perry AC, Zuccotti M, Johnson KR, Yanagimachi R. Full-term development of mice from enucleated oocytes injected with cumulus cell nuclei. Nature 1998; 394: 369-374. [Medline]

4. Polejaeva IA, Chen SH, Vaught TD, Page RL, Mullins J, Ball S, Dai Y, Boone J, Walker S, Ayares DL, Colman A, Campbell KH. Cloned pigs produced by nuclear transfer from adult somatic cells. Nature 2000; 407: 86-90. [Medline]

5. Tian XC, Kubota C, Sakashita K, Izaike Y, Okano R, Tabara N, Curchoe C, Jacob L, Zhang Y, Smith S, Bormann C, Xu J, Sato M, Andrew S, Yang X. Meat and milk compositions of bovine clones. Proc Natl Acad Sci USA 2005; 102: 6261-6266. [Medline]

6. Humpherys D, Eggan K, Akutsu H, Hochedlinger K, Rideout WM 3rd, Biniszkiewicz D, Yanagimachi R, Jaenisch R. Epigenetic instability in ES cells and cloned mice. Science 2001; 293: 95-97. [Medline]

7. Humpherys D, Eggan K, Akutsu H, Friedman A, Hochedlinger K, Yanagimachi R, Lander ES, Golub TR, Jaenisch R. Abnormal gene expression in cloned mice derived from embryonic stem cell and cumulus cell nuclei. Proc Natl Acad Sci USA 2002; 99: 12889-12894. [Medline]

8. Xue F, Tian XC, Du F, Kubota C, Taneja M, Dinnyes A, Dai Y, Levine H, Pereira LV, Yang $\mathbf{X}$. Aberrant patterns of $\mathrm{X}$ chromosome inactivation in bovine clones. Nat Genet 2002; 31: 216-220. [Medline]

9. Kim EY, Park MJ, Park HY, Noh EJ, Noh EH, Park KS, Lee JB, Jeong CJ, Riu KZ, Park SP. Improved cloning efficiency and developmental potential in bovine somatic cell nuclear transfer with the oosight imaging system. Cell Reprogram 2012; 14: 305-311. [Medline]
10. Kim EY, Kim YO, Kim JY, Park MJ, Park HY, Han YJ, Mun SH, Oh CE, Kim YH, Lee SS, Ko MS, Park SP. In vitro development of somatic cell nuclear transfer embryo treated with flavonoid and production of cloned Jeju Black Cattle. Reprod Dev Biol 2010; 34: $127-134$.

11. Kim EY, Park MJ, Kim JY, Park HY, Noh EJ, Noh EH, Song DH, Oh CE, Kim YH, Mun SH, Lee DS, Ko MS, Riu KZ, Park SP. Production of cloned Jeju black cattle (Korean Cattle) from SCNT embryo using vitrification, one-step dilution and direct transfer technique. Reprod Dev Biol 2011; 35: 77-83.

12. Watanabe S, Nagai T. Health status and productive performance of somatic cell cloned cattle and their offspring produced in Japan. J Reprod Dev 2008; 54: 6-17. [Medline]

13. Kasai K, Sano F, Miyashita N, Watanabe S, Nagai T. Comparison of the growth performances of offspring produced by a pair of cloned cattle and their nuclear donor animals. $J$ Reprod Dev 2007; 53: 135-142. [Medline]

14. Yonai M, Kaneyama K, Miyashita N, Kobayashi S, Goto Y, Bettpu T, Nagai T. Growth, reproduction, lactation in somatic cell cloned cows with short telomeres. J Dairy Sci 2005; 88: 4097-4110. [Medline]

15. Wells DN, Forsyth JT, McMillan V, Oback B. The health of somatic cell cloned cattle and their offspring. Cloning Stem Cells 2004; 6: 101-110. [Medline]

16. Kim EY, Noh EH, Noh EJ, Park MJ, Park HY, Lee DS, Riu KZ, Park SP. Effect of glycosaminoglycans on in vitro fertilizing ability and in vitro developmental potential of bovine embryos. Asian-Aust J Anim Sci 2013; 26: 178-188.

17. Han SH, Cho IC, Kim JH, Ko MS, Kim YH, Kim EY, Park SP, Lee SS. Coat color patterns and genotypes of extension and agouti in Hanwoo and Jeju black cattle. J Life Sci 2011; 21: 494-501.

18. Kim T. Endangered Jeju cattle cloned. Korea Times 2009-8-31. http://www.koreatimes co.kr/www/news/tech/2009/08/12951015.html.

19. Smith LC, Bordignon V, Babkine M, Fecteau G, Keefer C. Benefits and problems with cloning animals. Can Vet J 2000; 41: 919-924. [Medline]

20. Bordignon V, Keyston R, Lazaris A, Bilodeau AS, Pontes JH, Arnold D, Fecteau G, Keefer C, Smith LC. Transgene expression of green fluorescent protein and germ line transmission in cloned calves derived from in vitro-transfected somatic cells. Biol Reprod 2003; 68: 2013-2023. [Medline]

21. Wells DN, Misica PM, Tervit HR, Vivanco WH. Adult somatic cell nuclear transfer is used to preserve the last surviving cow of the Enderby Island cattle breed. Reprod Fertil Dev 1998; 10: 369-378. [Medline]

22. Bourc'his D, Le Bourhis D, Patin D, Niveleau A, Comizzoli P, Renard JP, ViegasPequignot E. Delayed and incomplete reprogramming of chromosome methylation patterns in bovine cloned embryos. Curr Biol 2001; 11: 1542-1546. [Medline]

23. Lanza RP, Cibel JB, Faber D, Sweeney RW, Henderson B, Nevala W, West MD, Wettstein PJ. Cloned cattle can be healthy and normal. Science 2001; 294: 1893-1894. [Medline]

24. Shiga K, Umeki H, Shimura H, Fujita T, Watanabe S, Nagai T. Growth and fertility of bulls cloned from the somatic cells of an aged and infertile bull. Theriogenology 2005; 64 334-343. [Medline] 